\title{
О.Я. Михалойко
}

\section{КОНЦЕНТРАЦІЙНІ ЗМІНИ ПЛАЗМОВОГО ГОМОЦИСТЕЇНУ ПРИ ГОСТРОМУ ІШЕМІЧНОМУ ІНСУЛЬТІ}

ДВНЗ «Івано-Франківський національний медичний університет»

\begin{abstract}
Резюме. У статті описаний взаємозв 'язок гіпергомоцистеїнемії (ГГЦ) із виникненням гострого ішемічного інсульту (ГІІ). У ході дослідження виявлено значну ГГЦ у хворих на ГІІ тяжкого ступеня, преморбідний фон яких включав артеріальну гіпертензію, цукровий діабет, церебральний атеросклероз. Відмічена гендерна
\end{abstract}

Вступ. Цереброваскулярні захворювання займають лідируючі позиції в структурі захворюваності, інвалідності та смертності, що визначає актуальність цієї проблеми в сьогоденні й зумовлює велику зацікавленість науковців та клініцистів у її вирішенні.

Традиційне уявлення про розвиток інсульту i цереброваскулярної патології пов'язане $з$ підвищеним артеріальним тиском, гіперхолестеринемією, цукровим діабетом, надмірною вагою, порушеннями ритму серця, гіподинамією [2, 6, 8]. Однак великомасштабне дослідження ВОO3 MONICA, проведене в 21 країні світу, показало, що дані фактори повністю не пояснюють розвитку ряду судинних захворювань. Тому, в останні роки інтенсивно досліджуються патогенетичні механізми ураження церебральних судин, а особливо «нові» чинники судинних уражень, так звані метаболічні фактори ризику, ідентифікація яких дала б можливість запобігти розвитку судинних катастроф. Серед них лідируючу позицію займає гіпергомоцистеїнемія (ГГЦ).

Гомоцистеїн (ГЦ) - сірковмісна амінокислота, проміжний продукт метаболізму метіоніну i цистеїну. За результатами ряду клінічних та епідеміологічних рандомізованих досліджень, проведених у різних країнах світу, встановлено, що ГГЦ одна 3 найсерйозніших причин атерогенезу, що призводить до багатьох потенціально фатальних патологій. За даними клінічних досліджень, збільшення концентрації ГЦ у плазмі на 5 мкмоль/л збільшує ризик серцево-судинних захворювань і загальної смертності в 1,3-1,7 раза $[1,6]$.

Згідно з рекомендаціями Американської асоціації кардіологів, концентрація ГЦ у крові 10 мкмоль/л є межовим рівнем, особливо за наявності супутніх захворювань, що можуть викликати підвищення вмісту ГЦ. Серед них зниження екскреторної функції нирок, серцево-судинні ураження, гіпотиреоз, цукровий діабет, гіперурикемія $[3,7]$.

До чинників, що впливають на рівень ГЦ та збільшують вірогідність його вмісту у крові, відносять вітамінодефіцитні стани, паління, зловживання алкоголем, дієту 3 підвищеним вмістом м`ясних та холестериновмісних продуктів. Відомо також, що причиною ГГЦ можуть бути спадкові захворювання, зумовлені дефіцитом ензимів, які беруть участь у його метаболізмі $[2,4,5]$.

(с) О.Я. Михалойко, 2016

84 та вікова залежність вираженості ГГЦ у пацієнтів із ГІІ. Так, вищі показники ГЦ фіксувались у чоловіків порівняно $з$ жінками та в осіб літнього та старечого віку.

Ключові слова: ішемічний інсульт, гомоцистеїн, гіпергомоцистеїнемія.

Атака інтими ГЦ призводить до травматизації ендотелію, куди осідає кальцій і холестирин, що сприяє утворенню атеросклеротичної бляшки, яка, у свою чергу, призводить до звуження просвіту судин. Більше того, високий рівень ГЦ стимулює агрегацію тромбоцитів; порушує функцію тканинного активатора плазміногена; інгібує функцію природних антикоагулянтів, таких, як антитромбін III і протеїн C; стимулює V, X, XII фактори згортання крові, зумовлюючи посилення тромбоутворення $[1,3,8]$.

Враховуючи суттєвий негативний вплив ГЦ на судинну стінку та недостатне обгрунтування його ролі саме при ГІІ, об'єктом нашої цікавості стало питання вивчення поширеності ГГЦ у хворих на ГІІ, а також з'ясування залежності концентраційних змін ГЦ від статі та віку пацієнтів, що $€$ досить актуальним і становить вагомий науковий інтерес.

Мета дослідження. Визначити концентраційні зміни плазмового гомоцистеїну при гострому ішемічному інсульті залежно від ступеня тяжкості інсульту, статі та віку пацієнтів.

Матеріал і методи. Обстежено 120 пацієнтів віком від 46 до 75 років (66 чоловіків та 54 жінки) з гострим ішемічним інсультом (ГІІ). Всі хворі були госпіталізовані в перші 24-48 год від появи клінічних проявів захворювання. Діагноз верифікувався за даними нейровізуалізації за допомогою спіральної комп'ютерної та магнітнорезонансної томографії. Ступінь тяжкості інсульту визначався згідно зі шкалою NIHSS. До контрольної групи входили 20 осіб без ознак гострих порушень мозкового кровообігу та тяжкої сома-

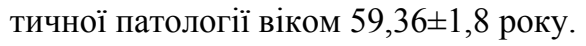

ГЦ у сироватці крові визначали імуноферментним методом за допомогою наборів Axis Homocysteine EL, виробництва Axis-Shield Diagnostics Ltd the Tehnology ParkDundee DD2, XA United Kingdom на 1-2-гу добу після виникнення захворювання.

Статистична обробка отриманих даних здійснювалася з використанням універсальних статистичних програм «Excel 5.0» до персонального комп ютера 3 визначенням середньої величини, стандартних відхилень, довірчого інтервалу. Для достовірності різниці між групами застосовували 
коефіцієнт Стьюдента (t). Відмінність між групами визнавалися достовірними при $\mathrm{p}<0,05$.

Результати дослідження та їх обговорення. Рівень ГЦ у осіб контрольної групи становив $8,45 \pm 0,30$ мкмоль/л. У всіх обстежуваних хворих на ГІІ на 1-2-й день захворювання вміст ГЦ відповідав 17,57 $\pm 1,1$ мкмоль/л та, відповідно, був вірогідно вищим порівняно 3 контролем $(\mathrm{p}<0,001)$. Рівень плазмового ГЦ коливався в широких межах. Так, у 14,1 \% пацієнтів рівень плазмового ГЦ був помірно підвищеним (до 10 мкмоль/л), у 45,8 \% - підвищеним (від 11 до 15 мкмоль/л) і в $40 \%$ - значно підвищеним (від 16 до 26 мкмоль/л). Слід відмітити, що у хворих на ГІІ у вертебро-базилярному басейні, який виник у результаті екстравазальної компресії на фоні остеохондрозу шийного відділу хребта, рівень ГЦ був на рівні верхньої межі норми, що вказує про відсутність впливу ГЦ на деструктивні зміни в міжхребцевих дисках. Значно вищі показники ГГЦ відмічались у пацієнтів із ГІІ тяжкого ступеня, преморбідний фон яких включав артеріальну гіпертензію в поєднанні з церебральним атеросклерозом та цукровим діабетом, 3 наявністю в анамнезі кількох тромботичних епізодів (транзиторні ішемічні атаки, ішемічний мозковий інсульт, інфаркт міокарда), і сягали 25,3 $\pm 0,3$ мкмоль/л.

У ході дослідження нами помічено достовірне зростання рівнів плазмового ГЦ залежно від ступеня тяжкості інсульту порівняно з показниками осіб контрольної групи (табл. 1). Так, у 14,1 \% пацієнтів із інсультом легкого ступеня тяжкості, рівень ГЦ склав $10,8 \pm 0,12$ мкмоль/л $(\mathrm{p}<0,05) ; \mathrm{y}$ 45,8 \% пацієнтів з інсультом середнього ступеня

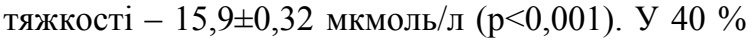
пацієнтів із тяжким інсультом показники ГГЦ були найсуттєвіші і зростали практично вдвічі порівняно 3 групою контролю та становили $19,5 \pm 0,5$ мкмоль/л $(\mathrm{p}<0,001)$.

Слід зазначити, що в процесі дослідження підвищення плазмового ГЦ виявилося більше в осіб чоловічої статі, ймовірно, це пояснюється особливістю способу життя чоловіків та більшим впливом несприятливих чинників на метаболізм ГЦ, до яких відносять тютюнопаління, зловживання алкоголем, дієта 3 підвищеним вмістом холестериновмісних продуктів. Існує гіпотеза, що нижчий рівень ГЦ у жінок порівняно з чоловіками пов'язаний із гормональними відмінностями. Така думка грунтується на факті достовірно

Таблиця 1

Показники плазмового гомоцистеїну в паціснтів із гострим ішемічним інсультом залежно від ступеня тяжкості за шкалою NIHSS

\begin{tabular}{|c|c|c|c|c|c|}
\hline \multirow{3}{*}{$\begin{array}{c}\text { ГЦ (мкмоль/л) } \\
(\mathrm{M} \pm \mathrm{m})\end{array}$} & \multicolumn{3}{|c|}{ Ступінь тяжкості ГІІ за шкалою NIHSS } & $\begin{array}{c}\text { група контролю, } \\
\mathrm{n}=20\end{array}$ & $\begin{array}{c}\text { пацієнти з ГІІ, } \\
\mathrm{n}=120\end{array}$ \\
\hline & Легкий $(\mathrm{n}=17)$ & Середній $(\mathrm{n}=55)$ & Тяжкий $(\mathrm{n}=48)$ & & \\
\hline & $\begin{array}{c}10,8 \pm 0,12 \\
\mathrm{p}<0,05\end{array}$ & $\begin{array}{c}15,9 \pm 0,32 \\
\mathrm{p}<0,001 \\
\mathrm{p}_{1}<0,05\end{array}$ & $\begin{array}{c}19,5 \pm 0,5 \\
\mathrm{p}<0,001 \\
\mathrm{p}_{1}<0,001 \\
\mathrm{p}_{2}<0,05\end{array}$ & $8,45 \pm 0,30$ & $\begin{array}{c}17,14 \pm 0,62 \\
\mathrm{p}<0,001\end{array}$ \\
\hline
\end{tabular}

Примітка. $\mathrm{p}$ - достовірність різниць показників порівняно з групою контролю; $\mathrm{p}_{1}-$ достовірність різниць показників із середнім та тяжким ступенем тяжкості інсульту до легкого; $\mathrm{p}_{2}$ - достовірність різниць показників із середнім ступенем тяжкості інсульту до тяжкого

Таблиця 2

Показники плазмового гомоцистеїну залежно від статі пацієнтів із гострим ішемічним інсультом

\begin{tabular}{|c|c|c|}
\hline Стать пацієнтів із ГІІ у ВББ & $\%$ & ГЦ (мкмоль/л) $(\mathrm{M} \pm \mathrm{m})$ \\
\hline Чоловіки $(\mathrm{n}=66)$ & 55 & $18,14 \pm 0,42$ \\
\hline Жінки $(\mathrm{n}=54)$ & 45 & $14,54 \pm 0,32$ \\
\hline ГЦ $(\mathrm{M} \pm \mathrm{m})(\mathrm{n}=120)$, мкмоль/л & \multicolumn{2}{|c|}{$17,14 \pm 0,62$} \\
\hline
\end{tabular}

Таблиця 3

Показники плазмового гомоцистеїну залежно від віку пацієнтів із гострим ішемічним інсультом

\begin{tabular}{|c|c|c|c|c|}
\hline & \multicolumn{4}{|c|}{ Вік хворих з ГІІ у ВББ $(\mathrm{n}=120)$} \\
\cline { 2 - 5 } & $40-49$ років & $50-59$ років & $60-69$ років & $70-79$ років \\
\hline Кількість пацієнтів & 5 & 41 & 59 & 15 \\
\hline $\begin{array}{c}\text { ГЦ (мкмоль/л) } \\
(\mathrm{M} \pm \mathrm{m})\end{array}$ & $12,14 \pm 0,31$ & $\begin{array}{c}16,14 \pm 0,34 \\
(\mathrm{p}<0,05)\end{array}$ & $\begin{array}{c}18,14 \pm 0,42 \\
(\mathrm{p}<0,05)\end{array}$ & $\begin{array}{c}20,14 \pm 0,32 \\
(\mathrm{p}<0,001)\end{array}$ \\
\hline
\end{tabular}

Примітка. р-достовірність різниць показників порівняно з групою контролю 
негативної кореляції між концентрацією естрадіолу і ГЦ у жінок у постменопаузі $[4,8]$.

Аналізуючи результати дослідження, нами встановлено взаємозв'язок між віком хворих та вираженістю ГГЦ. У пацієнтів старшого віку рівень плазмового ГЦ був вищий порівняно з пацієнтами молодшого віку. Так, показники ГГЦ були достовірно вищими порівняно 3 контролем у групі пацієнтів, віковий ценз яких був у межах 50-59 $(16,14 \pm 0,34 ; \mathrm{p}<0,05)$ та $60-69$ років $(18,14 \pm 0,42$; $\mathrm{p}<0,05)$, у пацієнтів літнього віку (70-79 років) концентрація ГЦ у крові була найвищою $(20,24 \pm 0,32$; $\mathrm{p}<0,001)$ (табл. 3). Ці дані підтверджують результати ряду мультицентрових досліджень, згідно з якими у 23-62 \% осіб літнього віку спостерігається дефіцит вітаміну $\mathrm{B}_{12}$, фолієвої кислоти та піридоксину, які є кофакторами ГЦ $[6,8]$.

\section{Висновки}

1. Проведене дослідження показало, що поширеність гіпергомоцистеїнемії серед хворих із гострим порушенням мозкового кровообігу за ішемічним типом досить висока, особливо зростання показників плазмового гомоцистеїну спостерігалося у пацієнтів із гострим ішемічним інсультом тяжкого ступеня, який виникав на грунті артеріальної гіпертензії в поєднанні з церебральним атеросклерозом та цукровим діабетом. Це зумовлює включення у вторинну профілактику ішемічного інсульту вітамінів групи В та фолієвої кислоти, які $\epsilon$ кофакторами гомоцистеїну i сприяють зниженню його вмісту у крові.

2. Встановлено взаємозв'язок між віком хворих та вираженістю гіпергомоцистеїнемії. У пацієнтів із гострим ішемічним інсультом старшого віку рівень плазмового гомоцистеїну був вищий порівняно з пацієнтами молодшого віку.
3. Прослідковувалися вищі показники плазмового гомоцистеїну в осіб чоловічої статі, що пояснюється більшим впливом несприятливих чинників на його метаболізм (тютюнопаління, зловживання алкоголем, дієта 3 підвищеним вмістом холестериновмісних продуктів).

Перспективи подальшого дослідження полягають у визначенні динаміки концентраційних змін ГЦ у ході терапії ГІІ з використанням у традиційній диференційованій терапії ГІІ різних нейропротекторних засобів та вітамінів групи В.

\section{Література}

1. Безсмертна Г.В. Метаболічні фактори ризику у хворих 3 ішемічним інсультом / Г.В. Безсмертна // Укр. мед. часопис. -2005 . - № 4. - С. 79-82.

2. Взаимоотношения гомоцистеина с системой гемостаза и возможности медикаментозной коррекции у пациентов с цереброваскулярной патологией и факторами риска ее развития / Д.А. Филимонов, С.К. Евтушенко, Д.Ш. Дюба [та ін.] // Укр. вісн. психоневроз. - 2012. - Т. 20, № 3 (72). C. 147.

3. Gugliucci A. Antithrombin activity is inhibited by acrolei$\mathrm{n}$ and homocysteine thiolactone: Protection by cysteine / A. Gugliucci // Life Sci. - 2008. - № 82 (Feb 13). P. 413-418.

4. Plasma homocysteine and MTHFRC677T polymorphism as risk factors for incident dementia / Andrew H. Ford, Leon Flicker, Helman Alfonso [et al.] // J. Neurol. Neurosurg. Psychiatry. - 2012. - Vol. 83. - P. 70-75.

5. Spence J.D. Homocysteine-lowering therapy: a role in stroke prevention / J.D. Spence // Lancet Neurol. - 2007. - Vol. 6. - P. 830-838.

6. Trabetti E. Homocysteine, MTHFR gene polymorphisms, and cardio-cerebrovascular risk / E. Trabetti // J. Appl. Genet. - 2008. - Vol. 49. - P. 267-282.

7. The oxidative stress may be induced by the elevated homocysteine in schizophrenic patients / A. DietrichMuszalska, J. Malinowska, B. Olas [et al.] // Neurochem. Res. - 2012. - Vol. 37 (5). - P. 1057-1062.

8. Williams K.T. Homocysteine metabolism and its relation to health and disease / K.T. Williams, K.L. Schalinske // Biofactors. -2010 . - № 36. - P. 19-24.

\section{КОНЦЕНТРАЦИОННЫЕ ИЗМЕНЕНИЯ ПЛАЗМЕННОГО ГОМОЦИСТЕИНА ПРИ ОСТРОМ ИШЕМИЧЕСКОМ ИНСУЛЬТЕ}

\section{О.Я. Михалойко}

Резюме. В статье описана взаимосвязь гипергомоцистеинемии (ГГЦ) с возникновением острого ишемического инсульта (ОИИ). В ходе исследования выявлено значительную ГГЦ у больных ОИИ тяжелой степени, преморбидный фон которого включал АГ, сахарный диабет, церебральный атеросклероз. Отмечена гендерная и возрастная зависимость выраженности ГГЦ у пациентов с ОИИ. Так, более высокие показатели ГЦ фиксировались у мужчин по сравнению с женщинами и у лиц пожилого и старческого возраста.

Ключевые слова: ишемический инсульт, гомоцистеин, гипергомоцистеинемия.

\section{CONCENTRATION CHANGES OF PLASMA HOMOCYSTEINE IN ACUTE ISCHEMIC STROKE}

\section{O.Ja. Mykhaloiko}

Abstract. This article describes the relationship between hyperhomocysteinemia (HHC) and the occurrence of acute ischemic stroke. The study found significant HHC in patients with acute ischemic stroke whose severe premorbid background included hypertension, diabetes, cerebral arteriosclerosis. Gender and age dependence of HHC severity in patients with ischemic stroke has been noted. Higher levels of HC were fixed in men compared with women and in elderly and senile age people.

Key words: ischemic stroke, homocysteine, hyperhomocysteinemia.

SHEE «National Medical University» (Ivano-Frankivsk)

Рецензент - проф. В.М. Пашковський

(c) О.Я. Михалойко, 2016

86
Buk. Med. Herald. - 2016. - Vol. 20, № 1 (77). - P. 84-86 